\title{
Usability of mathematical softwares in prostate screening
}

\author{
Mária Molnárné Nagy \\ University of Debrecen, Doctoral School of Information Science and Technology \\ nagymaria1@gmail.com
}

\begin{abstract}
This article discusses 4 mathematical software regarding the usage in the research phase of the PRO-FILTER, which will be a prostate screening computer service. This service is based on the PSA-level changes of the individual, the goal is to provide a prediction on the PSA-level, and from this future value propose a medical proceeding according to the state of the cancer.

The four mathematical software which were examined as possible tools are: Mathematica, Maxima, $\mathrm{R}$ and Scilab.

These tools were chosen because Maxima, $\mathrm{R}$ and Scilab are counted as powerful free solutions. The only proprietary program which was examined is the Mathematica.

The test case for each tool is a non-linear (quadratic) least square function fit. Each program is able to do it; some have multiple algorithms for it.

As a first test I did the estimation using the least square solution described in the manuscript [3]. It has simple steps, so each program is able to do it. The next step was to discover each tools statistical package, to find the function which uses non-linear least square data fit.

Each tool fulfills almost all the requirements. The plotting functionality of the Maxima has issues. The Mathematica is proprietary, but all other aspects of the program are ideal, currently the research has no resource to buy it. That leaves the Scilab and $\mathrm{R}$ system as best opportunities. The $\mathrm{R}$ is better for statistical analysis, it contains more special functions. But for quick numerical computations the Scilab is the better tool.
\end{abstract}

\section{References}

[1] CANGIANO, ANTONIO, 3 awesome free Math programs (02/06/2007) http:// math-blog.com/2007/06/02/3-awesome-free-math-programs/

[2] DOBÓ, ANDOR A rákos folyamat modell-családjának diszkutálása, Budapest, 07/06/2012, Manuscript 
[3] DOBÓ, ANDOR, Prosztatarák terjedésének matematikai leírása Budapest, 07/03/2012, Manuscript 